\title{
Kakasonist Kaljulaks
}

\section{Perekonnanimede eestistamise andmebaasi analüüs}

\author{
FRED PUSS
}

Nimi on oluline tunnus, mille põhjal tehakse isikut nägemata järeldus tema soo, rahvuse, sugulussuhete (patronüümid), sageli ka vanuse ning muude omaduste kohta. Kuna Eesti esimesel iseseisvusajal oli oluline rahvusriigi ülesehitamine, hakati rohkem tähelepanu pöörama ka nimede keelsusele. Tolleaegne nimede eestistamise kampaania puudutas sadu tuhandeid inimesi, kuid tegu on vaid osaliselt läbi uuritud teemaga. Selle taga on nähtud nii poliitilisi võtteid vaikival ajastul rahvale tegevuse pakkumise eesmärgil kui ka rahvuslikku algatust saamaks lahti „orjaöö” taagast. Nimede eestistamise eeskuju võeti Soomest, kuid õige hoog saavutati 1934. aasta riigipöörde järel tekkinud riikliku toetusega (Raun 2012).

Nimede rahvuskeelestamise kampaaniaid on tehtud näiteks nii XIX sajandil Ungaris, fašistlikus Itaalias (mõlemas küll vähemusrahvuste arvel), Teise maailmasõja järgses Poolas (Walkowiak 2016: 229, 235, 238) kui ka XX sajandi esimesel kolmandikul Soomes (Närhi 1987) ning vähesel määral Lätis (Staltmane 1977) jm. Kuigi nende kampaaniate käigus nimesid muutnud inimeste arv ulatub Eestiga sarnaselt sadadesse tuhandetesse (v.a Lätis), on Eesti kampaania unikaalne lühiajalisuse ja nimemuutjate osakaalu poolest elanikkonnast (iga kuues elanik!). Erinevalt teistest maadest on Eesti nimemuutmised onomastika andmebaasina (OA) juba mitukümmend aastat kõigile kättesaadavad: 1990. aastatel koostas üks digihumanitaaria pioneere Eesti ajalooteaduses (Tamm 2020: 42), Tartu Ülikooli arhiivinduse professor Aadu Must perekonnanimede paneku ja eestistamise andmebaasid. Aadu Mustalt 2000. aastate algul saadud algandmestikku (mis on väheste parandustega praegu veebis, vt $\mathrm{OA}$ ) on siinkirjutaja sellest ajast alates parandanud ja täiendanud. ${ }^{1}$

Praeguseks on digitaalselt kättesaadavad ka mitmed lisaandmestikud. Esiteks andmebaasi aluseks olnud Riigi Teataja Lisa tärktuvastus DIGAR-is ning nimemuutmiste toimikud, mis seni olid teaduskäibest eemal, kuna need anti alles 2020. aasta mais Siseministeeriumist Rahvusarhiivi. Seal koostatud toimikute kirjeldusandmed arhiiviinfosüsteemis AIS annavad OA-le hea võrdlus- ning kontrollivõimaluse. ${ }^{2}$ Samuti poleks soovitusnimestiku „Eesti nimi” tärktuvastuseta (DIGAR-is) olnud võimalik selle käsitelu.

\footnotetext{
${ }^{1}$ Tekstis viitab OA autori parandatud ja täiendatud versioonile. Kui on olnud vaja viidata algsele (avalikule) versioonile, on lisatud vastav selgitav sõna. Artiklis on kasutatud vaid OA eestistamise andmestikku.

${ }^{2}$ Autor tänab Rahvusarhiivi andmebaasi administraatorit Maiu Pevkurit toimikute andmete tabelkujul väljastamise eest ning Rahvusarhiivi arhivaari Andero Nimmerit toimikutes leiduvate andmete kontrollimise eest.
} 
Artiklis antakse ülevaade perekonnanimede eestistamise senisest uurimisest ja eestistamise korraldusest, kirjeldatakse probleeme nimemuutmiste andmestikega töötamisel ning kasutatakse OA-d koos võrdlusandmestikega nimemuutjate üldarvu, soovitusnimestiku mõju ning võetud nimede statistiliste omaduste (esitäht, pikkus, ainukordsus) analüüsiks.

\section{Historiograafia}

Eestistamise kampaania kõrgajal 1935-1940 ilmus peaaegu iga päev ajakirjanduses teemakohaseid teateid ning kuni 1940. aastani avaldati mõningaid üldisi kokkuvõtteid (nt Elisto 1938), kuid protsess ja sellest ülevaadete andmine vaibusid 1940. aastal.

Välis-Eestis puudutati nimede eestistamise teemat vaid põgusalt. Keeleteadlane Hildegard Must (1957: 285) andis eestistamist tutvustades hinnangu, et „rohkem traditsioonidest ja loomulikkudest eeskujudest kinnipidamist oleks olnud ettevõttele kasuks". Puudustena mainis ta ebamääraste ja kunstlike nimede ning mitte-eestikeelsete sõnavormide kasutust, talunimede alakasutamist ning kohati teadmatust uue nime(vormi) kokkulangemisest võõrapärasega (nt -ma lõpp kattub tüüpiliste friisi nimedega) (Must 1957: 285). Teised Välis-Eesti (sh baltisaksa) kirjutised olid valdavalt referatiivsed ja mälestuslikud (Raag 1971: 189-191; Angelus 1971; ArA 1971; Grönberg 1985; Nimede eestistamine 1987).

Nõukogude ajal nimemuutmist kui sügavalt rahvuslikku üritust avalikult ei uuritud. Kogumik „Eestlasele eesti nimi” (EEN 1921) ja uute perekonnanimede nimestik „Eesti nimi” (EN 1935) olid kantud keelatud kirjanduse nimekirja (Glavlit 1948: 16; Glavlit 1963: 29), nii nagu kaasaegnegi perioodika. Oma mälestustes Emakeele Seltsist vaikib eestistamise peaaegu täielikult maha ka seltsi pikaaegne sekretär ja eestistamistoimkonna liige Elmar Elisto (1976: 89, viidatud tekst ilmus esmakordselt 1960). Arnold Kase (1960: 6) koostatud ülevaates Emakeele Seltsi 40 aasta tegevusest oli võimalik mainida, et seltsi propageeritud eestistamine ei leidnud poolehoidu ning hakkas "mõnevõrra levima” alles 1930. aastatel. Kümme aastat hiljem kirjutas Kask (1970: 8, 12) mõne rea jagu pikemalt ning objektiivsemalt (1934. aastal hakkas eestistamine „muutuma hoogsamaks”). Edaspidigi ilmus teemast vaid mälestuskatkeid (Roos 1980), isegi viljakaim nimeuurija ning Nimede Eestistamise Keskbüroo juhataja Edgar Rajandi (Uut hoogu 1940) ei kirjutanud teemast midagi peale mõne lõigu (Rajandi, Tarand 1976: 135), kuigi tal oli nimemuutmistest eraldi materjalikogu (Rajandi 1978: 96).

Taasiseseisvunud Eestis ilmunud uurimused käsitlevad eestistamise õiguslikku külge (Henno 2002; Mõistlik 2005), organisatsioonide tegevust (Henno 2001; Leivategija 2011), aktsiooni üldist käiku (Rajasalu 1993) või poliitilist tausta (Vaan 2005: 48-55; Raun 2012). Aadu Must on OA-d tutvustanud nii konverentsidel (2006, 2010), õpik-käsiraamatutes $(2000,2015)$ kui ka ajakirjanduses (1999). Neis töödes on käsitletud ajalooalaseid andmebaase kogu maailmas ja OA koostamist, kuid selle analüüs on piirdunud vaid näidete ja üldkokkuvõtetega. 
Leidub mõningaid üliõpilastöid, kus OA-d on kasutatud piirkondliku nimemuutmise analüüsiks (Raidmaa 1999; Pärn 2013), ning selliste tööde panus on väiksema andmestiku detailne analüüs. Üldisem ülevaade aga puudub siiani.

\section{Perekonnanimede muutmise korraldus}

1919. aasta detsembris vastu võetud perekonnanime muutmise seadus (RT 1920, $2 / 3,15)^{3}$ andis r i i i k o h t u l e õiguse nime muutmise otsustamiseks. Nime võisid muuta vaid Eesti kodanikud ning põhjendusteks võisid olla „halb tähendus, võõrakeelne või halb kõla või sugukonnanime alalhoidmise soov". Muutmisprotsess kestis umbes pool aastat. Protsessi keerukuse ning kalliduse tõttu läbisid selle vaid vähesed inimesed.

OA-s on 539 riigikohtu tehtud muutmisotsust. Tolle perioodi andmestikus on maapiirkonnad n-ö üleesindatud: umbes pooled tsaariajal maal hingekirjas olnud (ning sellisena muutmisotsuses ja seega ka OA-s näidatud) inimestest elasid vabariigi algusajal linnas. Näiteks Bernhard ja Helmi Mühlberg > Mäelo elasid Tartus, kuid olid hingekirjas Kuigatsi vallas ning see on muutmisotsuses nendega seostatav ainus kohanimi. ${ }^{4}$ Samuti Friedebert Mihkelson > Tuglas elas koos abikaasaga Tartus, kuid muutmisotsuses kajastub hingekirjutuse koht Ahja vald. Sel põhjusel ei näitaks olemasolevate andmete põhjal tolle perioodi nimemuutmiste geograafiline uurimine tegelikkust objektiivselt, näiteks nimemuutmiste kese Tartu linn on andmete esitusviisi tõttu alaesindatud.

1919. aasta seadusest sõltumatult võidi oma võõrkeelse kõlaga perekonnanime muuta Petserima ja Narvataguse elanikele perekonnanimede panekuks moodustatud k o m i s j o n i d e s (RT 1921, 26, 21). Aastail 1921-1923 kasutati seda võimalust 908 korral. Seda tuleks erinevalt senisest lugeda nimede eestistamise osaks, ent kuna tegu on eraldi andmekoguga, mille analüüs pole artikli eesmärk, on need välja jäetud. Muutmised hõlmasid ligikaudu 2000-3000 inimest, kes peamiselt vahetasid ühe vene nime teise vastu (Šlopkin $>$ Akatsiev, Ustinov $>$ Baitsov). Enamasti polnud tegu fikseeritud perekonnanime muutmisega, vaid patro- või paponüümi või mitteametliku perekonnanime (vn уличная фамилия) asemele ametliku perekonnanime võtmisega. Mõnesajal korral on võetud ka eesti nimi. Nendel puhkudel vahetati eesti (halvakõlaline) nimi teise eesti nime vastu (Elevant $>$ Ant, Lirtse $>$ Seeder) või ka vene (Isvoštšik $>$ Ehavald) või saksa (Stamberg $>$ Haukanõmm) nimi eestipärase vastu. (PENA 1921-1923) Osa selliselt muudetud perekonnanimedest (Steinfeld > Kiviste) jõudis August Rava koostatud teatmikku (MN 1935) ning selle kaudu ka OA-sse, kuid tegu on üksikjuhtumitega.

\footnotetext{
${ }^{3}$ Riigi Teataja (RT) puhul on viidatud aastale, numbrile ning artiklile, Riigi Teataja Lisa (RTL) puhul aastale, numbrile ja leheküljele. Sama kehtib nende jätkajate Eesti NSV Teataja (Lisa) ja Ametliku Teataja kohta.

${ }^{4}$ Teksti koormamise vältimiseks pole näidete viiteid esitatud. Need on OA-st hõlpsasti leitavad ning viite kaudu leiab muutmisotsuse Riigi Teataja Lisast, mis on digiteerituna olemas DIGAR-is.
} 
Perekonnanimede muutmise seadus (RT 1930, 57, 388) andis otsustamise alates 1. augustist 1930 (VT 1934: 214) riigikohtult k o h t u- ja s i s e m in is t r il e. ${ }^{5}$ Peale eelmises seaduses mainitud muutmispõhjuste lisati loetellu ka nime lai levik. Kulud ning menetlusaeg jäid varasemaga sarnaseks.

Nimekorralduse seadus (RT 1934, 52, 438) kaotas kaheks aastaks (juunist 1934 juunini 1936) nime eestistamise kulud (need jäid kehtima halvakõlalise nime muutmisel). Seadus lõi võimaluse mitmest nimeteisendist ehk rööpnimest üks valida (varem loeti seda perekonnanime muutmiseks) ning ka nimi kaitseregistrisse kanda.

Soovides sisepoliitiliselt pingsal ajal veelgi hoogustada nimede eestistamist, kehtestati 1934. aastal eelmise seaduse asemel perekonnanimede korraldamise seadus (RT 1934, 91, 735), millega loodi kaheks aastaks (1. jaanuarist 1935 kuni 1. jaanuarini 1937) nimede muutmise lihtsustatud kord. Sellega nähti siseministrile ette õigus anda mutmise otsustamine perekonnaseisua metnikele (mida minister ka tegi: RT 1934, 107, 841), vastuvaidlemise tähtaega lühendati kolmelt kuult ühele ja lisati tasuta muudetavate hulka ka halvakõlalised nimed. Tasuta nimemuutmise tähtaega pikendati hiljem 1. jaanuarini 1939 (RT 1937, 101, 820), seejärel 1. jaanuarini 1940 (RT 1938, 106, 921) ning lõpuks 1. jaanuarini 1941 (RT 1939, 115, 893). Osal juhtudel (vaidluste, rööpnimede kaotamise soovi, laialt levinud nime muutmise soovi jm) jäi otsustajaks siseminister ning vastuvaidlemise tähtajaks kaks kuud.

Sellest tulenevad järgmised ebakõlad andmebaasi andmestikus. Nagu riigikohtu otsustest ei selgu alati isiku elukoha omavalitsus, ei selgu see ka siseministri tehtud otsustest. Näiteks muutis minister Valga-Võru raudteeliinil raudteemajas nr 513b elava Artemon Muna (ka Jaitsov) nime (> Kallaste) või lihtsalt ilma elukohta mainimata otsustati nimemuutus Rudolf Kassuk > Talv. Siseministri otsustatud nimemuutmised (andmebaasis 1366 kirjet) on siinses analüüsis arvestatud Tallinna alla, kuna selle omavalitsuse andmetes mõjutavad need tulemust kõige vähem (Tallinna kohta on 12043 kirjet), ning arvestades üldise elanikkonna jaotust eestistamise tippaastal 1936 (Reiman 1936: 174), elaski nendest siseministri otsusega seotud 1366 inimesest $12,7 \%$ Tallinnas. Kuna tegu on üsna suure hulgaga, oleks edaspidi andmestike kättesaadavuse paranemisel (eelkõige tollaste perekonnaregistritena) vajalik elukoha omavalitsuste täpsustamine.

Alates muutmise otsustusõiguse üleminekust riigikohtult ministrile (1930) kuni muutmise lihtsustatud korra kehtima hakkamiseni 1. jaanuaril 1935 on andmebaasis 514 kirjet. Neile lisanduvad detsembris 1934 ja jaanuaris-veebruaris 1935 tehtud ja hiljem Riigi Teataja Lisas ilmunud otsused, kuna esimene perekonnaseisuametniku otsus nimemuutmise kohta ilmus alles 1. märtsil 1935 (RTL 1935, 17, 631). Kokku on seega siseministri ainuotsustuse ajal registreeritud 652 nimemuutust.

Nimede eestistamine ei lõppenud 1940. aastaga, nagu seda tavatsetakse arvata ja nagu OA avalik versioon seda kajastab. 1940. aastal alanud esimese Nõukogude okupatsiooni ajal nimede eestistamine esialgu jätkus ja viimased otsused ilmusid 3. detsembril 1940 (ENSV TL 1940, 28, 443). 1. jaanuarist 1941 hakkas Eestis kehtima Vene NFSV abielu-, perekonna- ja eestkosteseaduste koodeks (ENSV T 1940,

${ }^{5}$ 1. aprillil 1934 toimunud ministeeriumide lahutamise järel allus nimemuutmine Siseministeeriumile (RT 1934, 5, 36). 
$73,1007)$ ning sellega katkes nimede muutmine seni kehtinud korra alusel. Saksa okupatsiooni ajal Eestis kehtiva õiguse määrusega (AT 1941, 2, 8) jõustusid taas Eesti Vabariigi seadused ja määrused ning perekonnanimede korraldamise seaduse alusel otsustas nimemuutmisi edaspidi sisedirektor. Perekonnaseisuametnikele enam seda õigust ei antud.

Ametliku Teataja III osas avaldati 8. juunist 1942 kuni 31. juulini 1944 kokku 138 sisedirektori nimemuutmisotsust, kusjuures väljaande viimases numbris ilmus veel seitse muutmise sooviavaldust (AT III 1944, 32, 546). Et otsused ilmusid väljaandes kuu aja pärast või hiljemgi, võidi muutmisotsuseid teha veel augustis ja septembris 1944, aga need jäid väljaande katkemise tõttu avaldamata. Näiteks võttis sisedirektoorium 16. augustil 1944 vastu riigilõivu nimemuutmise Buschkov > Männits ja 18. augustil 1944 nimemuutmise Kommusaar > Poola kuulutuse avaldamiseks (RA, ERA.5201.2.47594b; RA, ERA.5201.2.47594d). Sisedirektori muutmisotsused on lisatud OA-sse. Suurem täiendus on 1938. aasta sügise muutmisotsused (1479 kirjet), mis puuduvad siiani OA avalikust versioonist.

\section{Onomastika andmebaasi probleemid}

Erinevalt OA perekonnanimede paneku osast (mis oli relatsiooniline andmebaas) oli eestistamise andmestik algselt päringuvormiga tabel. Andmebaasi iga kirje sisaldab nelja välja: endine perekonnanimi, uus perekonnanimi, kuulutuse avaldanud Riigi Teataja Lisa kuupäev, muutmise koht ehk otsuse teinud perekonnaseisuametniku omavalitsus. Kirjeid on algversioonis 78 687, pärast siinkirjutaja täiendusi ja korduvkannete liitmist 76 364. Siinse analüüsi jaoks tehtud korrastamise käigus tehti tabelist relatsiooniline andmebaas, eraldades kohanimed eraldi tabelisse (vt ptk „Haldusjaotuse andmestik”). Samuti loodi lisaväljad, mida on andmete täpsustamise käigus täidetud vastavalt vajadusele. Suuremad muutused olid tegelemine mitme variandiga nimedega, haldusüksustega, samuti andmestiku analüüsil ilmnenud üksikute puudustega. Järgnevalt kirjeldatakse neid probleeme lähemalt.

\section{Nimevariandid, korduvad kanded}

Ühel isikul võis esineda mitu erinevat perekonnanime. Reeglina oli rööpnimede puhul üks kasutusel kirikuraamatutes, teine hingeloendites ja nende funktsiooni jätkavates valladokumentides. Perekonnaregistri sisseseadmisega 1926. aastal pidi ametlikuks kasutuseks valitama sünnisissekande ehk kirikuraamatu nimekuju ning seetõttu valladokumentides olnud rööpnimed valdavalt hääbusid. (Puss 2020)

OA algversioonis olid rööpnimedest ning ka ühe nime eri kirjapiltidest moodustatud eraldi kirjed (Noks > Ehasaar ja Noksman > Ehasaar). Ühe muutmise kohta oli kuni kuus eri kirjapilti, seega oli kunstlikult juurde tekitatud kuni viis kirjet. Need ühendati nüüd lisavälja abil üheks kirjeks (Noks Noksman > Ehasaar). ${ }^{6}$

\footnotetext{
${ }^{6}$ Nimetatud töö tegi oma uurimistöö osana Hugo Treffneri gümnaasiumi õpilane Mihkel Paloots 2020. aasta kevadel.
} 
Kaks või enam varianti või mitmiknimi esinevad OA-s 5148 kirjel. Tollal ei olnud mitmiknimed tavaliselt abielunaistel nagu tänapäeval, vaid tegu oli rööpnimedega ja nii on neid siin analüüsis ka käsitletud. Mitme nimevariandiga kirjetest 477 on juhud, kus üks eelmistest variantidest või mitmiknime komponentidest kattub uue nimega (Pankrot-Pank > Pank) ning seega pole tegu nime eestistamisega. Rööpnimede kaotamisena on siinkohal käsitletud ka neid, kus ükski eelmistest fikseeritud nimekujudest ei kattunud täpselt, kuid on näha soovi kahest nimest üks valida (Tomson-Meus > Meos), või tehti koos rööpnime kaotamisega ka ilma muutmisprotsessita lubatud õigekirjutuslik parandus (Hanssen-Tagasar > Tagasaar). Rööpnimede kaotamiseks pole loetud neid, kus peale kahe nime kaotamise nimi ka eestistati (Käsper-Kesper > Käspre). Üksikud juhtumid jäävad ortograafia tõttu arvutianalüüsil ja silmvaatlusel leidmata, kuigi tegu on samuti rööpnimede kaotamisega, nt Miilberg Miilperk Uustallu $\sim$ Uustallo $>$ Uustalu või Jas Jazi > Jaasi. Rööpnimede kaotamistest 208 otsustati enne, 269 pärast 1. jaanuari 1935, seega on nende osakaal kõikidest muutmistest enne nimemuutmise lihtsustatud korda oluliselt suurem.

OA algversioonis oli rööpnimede puhul enamasti sisestatud vaid alles jäävaga mittekattuv nimi, st Aavekukk Aurvekukk > Aavekukk sisestati kui Aurvekukk > Aavekukk. Siinkirjutaja tegi andmekontrollil selliste rööpnimede kohta mitusada parandust. Tõenäoliselt on selliseid kirjeid veel kuni pool tuhat, nendest mõnisada on rööpnimede kaotamise otsused ning seda arvestades peaks nimemuutjate üldarvust maha võtma veel kuni 300. See moodustab vaid 0,4\% kirjete koguarvust ega mõjutaks lõpptulemust. Rööpnimede kaotamise kirjed (477) märgistati eraldi ning need on edaspidisest analüüsist välja jäetud.

Kui rööpnimede ja eri kirjapildiga kirjete liitmisel kahanes eestistamiskirjete hulk oluliselt (5148 kirje ehk 6\% võrra), siis lahendamata jääb probleem, kus kirjeid peaks olema hoopis rohkem (vt lk 806).

\section{Üksikjuhtumeid}

OA töötlusel ning algandmestikuga võrdlemisel ilmnes huvitavaid üksikjuhte, mille tõttu andmebaasi on jõudnud kas ebatäpsused või tuleks neid edaspidi andmete täiendamisel eristada, sest tegu ei olnud endale vana nime asemele uue võtmisega. Nende hulk on minimaalne, kuid need on siinkohal esitatud illustreerimaks, et kogu toimunud protsess ning seda andmebaasina kajastav andmestik ei olnud ühetaoline.

1935. aasta veebruarini on nimed RTL-i kuulutuses käändes (Koogile, Vaesele, Erelisele) ja kuni jaanuarini 1935 mõnikord apostroofita (hiljem olenevalt perekonnaseisuametniku saadetud andmetest enamasti apostroofiga). Seetõttu pole alati õigesti tuletatud nime nominatiivne kuju: näiteks nimest Sipsakale tekkis OA algversiooni Sipsak pro Sipsaka.

Leidub üksikjuhtumeid, kui taastati oma esialgne nimi. 1921. aastal võttis Johannes Muks koos perega Narvas sealse nimepanekukomisjoni otsusega uueks nimeks Roosilill, kuid 1926. aastal võttis ta nime Muks tagasi. Hiljemalt 1935. aastal on 
asutud seisukohale, et „perekonnanime saab muuta üks kord” (Siseministeeriumi ringkiri perekonnaseisuametnikele 24. V 1935, avaldatud Mõistlik 2005: 165), kuid siinkirjutajal pole õnnestunud leida sellisele seisukohale juriidilist alust.

Mitmekordset muutmist esines teistelgi põhjustel. Pärast eelmainitud rööpnimede kaotamist mõnikord ka see ainus nimi eestistati. Näiteks Johannes Nebukat $\sim$ Mihelson $\sim$ Mihkelson jättis endale 1934. aastal ainsaks nimeks Mihelson, kuid juba aasta hiljem eestistas ta selle nimeks Mihklisoo. Sellised nimemuutjad koos oma perekonnaliikmetega kajastuvad nimemuutjate hulgas kaks korda. Siiski on nende hulk väga väike ning praeguste andmestike põhjal pole neid ka võimalik leida.

Harvadel juhtudel võeti endale (tagasi) ka rööpnimed ja hiljem neist loobuti. Näiteks 1926. aastal võttis Emilie-Rosalie Kallus pärast lahutust tagasi oma eelmise, surnud mehe nime Leu (Lõiv) ja 1939. aastal jättis neist alles vaid nime Lõiv.

Mõned nimemuutmised viidi küll lõpule, kuid muudetud nime ei hakatud kasutama. Roela valla perekonnaseisuametnik määras 13. V 1940 perekond Voltenbergile uueks perekonnanimeks Kaldoja, kuid nad elasid edasi Voltenbergi nimega (Haudi, 10. V 2021). Palju sagedamini esines seda Eestist lahkunute puhul.

Senine nimi vahetati mõnikord oma varasema (mitte viimase) abikaasa nime vastu (Tiits $>$ Kõiv), võeti endale poja nimi (Grauding > Falk), üsna sageli võeti tagasi enda neiupõlvenimi (Kiiranen $>$ Sepp, Huene $>$ Aksenova, Majer $>$ Alver) või ühiselt naise neiupõlvenimi (Titma $>$ Toodu), samuti ema neiupõlvenimi ( Unt $>A u s$ ). Korduvalt muutis ema oma alaealise lapse nime enda nimega samaks (Tillart $>$ Endrikson), samuti täisealine vallaslaps võttis ema abielunime (Martinson > Sommer). Muudeti enda nimega samaks ka oma kasulapse ehk mitte lapsendatud lapse nimi (Poker $>$ Juurikas, Juhanson $>$ Riikson), võeti ka lahutatud abikaasa nimi (Tarkpea > Padalka).

Ühelgi eelnimetatud juhul ei olnud võetud nimi uus, vaid perekonnas varem olnud või tolgi hetkel eksisteeriv nimi. Kui kasulaste või vallaslaste nime muutmine oli pigem erand ning seda tehti tõenäoliselt peamiselt 1920. aastatel, siis abielupaari puhul naise neiupõlvenime või emma-kumma abikaasa ema neiupõlvenime uueks nimeks võtmine on huvitav uurimisteema, milleks saab kasutada Siseministeeriumis juba sisestatud, kuid avalikkusele seni ilma juurdepääsuta 1926.-1949. aasta perekonnaregistri andmebaasi. Selgi juhul oleks tulemuslik kasutada laiendatud lähenemist, näiteks sarnaseid nimesid tuvastavate algoritmide abil. Nii võib leida ka juhtumi, kus Voldemar-Gustav Korner võttis endale uueks nimeks Lillepott, sest tema ema neiupõlvenimi oli Lilleput.

\section{Haldusjaotuse andmestik}

Nimede eestistamise ajal muudeti halduspiire ning toimus vallareform. Aastail 1922-1934 kaotati üheksa valda, 1. aprillil 1939 aga 117 valda. Kaotatud valdade perekonnaseisuraamatutes sündide, abielude ja surmade registrid lõpetati, kuid perekonnaregistreid polnud võimalik jaotada mitme valla vahel ning need läksid üle ühele uuele vallale (Teder 1939: 141-142). Perekonnaregistrite liitmine (andmestikku vt Teder 1939: 367-379) on hea alus nimemuutmiste analüüsiks enne ja 
pärast vallareformi, sest samal põhimõttel on arhiivis korraldatud ka nimemuutmistoimikud.

Probleeme on aga samanimeliste omavalitsustega, millele on tähelepanu juhtinud OA koostaja (Must 2000: 78-79). Ühelt poolt on tegu eri kohas asuvate omavalitsustega (näiteks Roela vald Tartumaal ja Virumaal), kuid teiselt poolt on andmesisestusel jäänud eristamata samanimeliste valla- ja alevi- või linnaomavalitsuste andmed, näiteks on Võru linna ja Võru valla andmed kõik Võru nime all.

Ajaloolise haldusjaotuse geoinfona on maa-ameti veebilehe kaudu kättesaadavad muuhulgas ka 1938. aasta omavalitsuspiiride andmed. ${ }^{7}$ Tegu on 1990. aastate teisel poolel koostatud andmetega, mis vajaksid praegu aga parandamist (Väinvere pro Väinjärve, Kõrgessaare pro Kõrgesaare jt) ning ka geoinfoandmete täpsustamist. Nii on seal kuus juhuslikku linna (nt Tallinn ja Kärdla) esitatud valdade kihis territooriumina, ülejäänud 12 linna vaid punktina, Otepää linn puudub andmestikust sootuks. OA ning olemasolevate ajalooliste geoinfoandmete ebaühtlus on üks põhjusi, miks artiklis pole kasutatud geograafilist visualiseerimist.

\section{Andmebaasi korrastamise tulemus}

Olles andmebaasi täiendanud 1938. aasta sügise ja 1942.-1944. aasta andmetega ning parandanud tuhandeid kirjeid, kontrollinud silmvaatlusega andmebaasi eri versioonides esinevaid mittekattuvaid kirjeid (mis osutusid enamasti sisestusvigadeks), ühendanud rööpnimedega ja eri kirjapildiga kirjed, kujunes kirjete koguhulgaks 76 364. Neist rööpnimede kaotamiseta ehk tegelikke nimede eestistamisi on 75887 kirjet, mis on edaspidise analüüsi aluseks. Järgnevalt kasutatakse saadud andmeid, et korrigeerida nimemuutjate üldarvu ning saada ülevaade soovitusnimestiku kasutamisest ja nimevõtjate maitse-eelistustest.

\section{Nimemuutjate üldarv}

Nimemuutjate üldarvu kohta oli pikka aega käibel vaid osaline statistika ning kuigi suurusjärk on olnud sama, on põhjust seda uute võimaluste avanemise järel täpsustada.

1938. aastal avaldas Elmar Elisto (1938: 52) Nimede Eestistamise Keskbüroo 1937. aastani kogutud andmed. Ta tõdeb, et esiteks pole teada nime eestistajate arv (st eristatuna halvakõlaliste nimede jmt muutmisest) ning teada on vaid sooviavalduste, mitte muutmisotsuste arv. Tegu on üldjuhul kattuvate arvudega ning nagu esitatud statistikast näha, on aastate 1935-1937 andmetel saadud isikute arv sooviavalduste arvu korrutamisel 2,5-ga, kuna see oli võetud keskmiseks ühise avalduse esitanud isikute arvuks. Täpne tundub olevat vaid aastail 1920-1934 nime muutnute $\operatorname{arv}(2672)$.

\footnotetext{
${ }^{7}$ https://geoportaal.maaamet.ee/est/Ruumiandmed/Haldus-ja-asustusjaotus/Ajalooline-haldusjaotus-p827.html (10. V 2021).
} 
Keskbüroo jõudis koostada ka statistika 1. jaanuarini 1940. Selles on esitatud nimede eestistamiste arv, seega jääb selgusetuks, kas see hõlmab kõiki nimemuutmisi. Nende andmete järgi eestistasid oma nime 1935.-1939. aastani 196482 isikut (RA, ERA.14.2.700, 1 288; sama RA, ERA.1068.1.1, 14). Kuigi see ei jagu täpselt 2,5-ga, ei ole tõenäoline, et tolleks ajaks oli olemas täpne statistika isikute tasemel, vaid sooviavalduste arv korrutati 2,5-ga ning ümardati täisarvuni. 22. märtsil 1938 kinnitas Nimede Eestistamise Liit Siseministeeriumile, et „isikute arvutamisel on iga sooviavalduse kohta arvestatud 2,5 isikut (mis on üleriigiline keskmine)" (RA, ERA.14.2.369, 18). Eeltoodud arvust 196482 puuduvad ka enne 1935. ja pärast 1939. aastat muudetud nimede andmed. Ühe nimemuutmise keskmiseks isikute arvuks peeti varem isegi kolme ning selle põhjal tehti ka statistikat (Salurand 1935).

Siseministeerium hindas 1. aprilliks 1939 nime muutnute arvuks 181000 (VT 1939: 101). Aprillist detsembrini 1939 ilmus 3378 nimemuutmisotsust (maksimaalselt 8500 inimest). Seega oli 1939. aasta lõpuks muutjaid kuni 190 000, mitte aga 199 154, nagu see oleks keskbüroo statistika põhjal (liites juurde kuni 1935. aastani nime muutnute arvu).

Arvestuse pooleli jäämine on mõjutanud ka hilisemaid hinnanguid. Inda Rajasalu on taasiseseisvunud Eestis ilmunud esimeses teemakohases kirjutises esitanud 1. detsembrini 1939 nime muutnute arvuks 195 000, toetudes teksti järgi keskbüroo tabelile, kuigi viited on kuni 1938. aastani ilmunud allikatele (Rajasalu 1993: 104, 106).

ENE ja EE esitavad aastail 1935-1940 nime eestistanute arvuks „umbes 211000 isikut" (ENE 1974: 83; EE 1994: 255). Aadu Must (2010: 399, 2015: 66) on hiljemalt 2002. aastast toonud käibele nimemuutjate arvuna 210 000. Entsüklopeedia „Eesti. A-Ü” esitab arvatavasti Musta tsiteerides arvuks „ligi 210 000” (EE 2003: 409). Kõige täpsema arvu (213 670) toob Ilona Raidmaa (1999: 10), paraku pole ka koos temaga õnnestunud siinkirjutajal selle allikat tuvastada. Sageli kasutatakse viimast kaasaegset statistikat („ligi” või „umbes” 200 000), mis ulatus 1939. aasta lõpuni (Karjahärm, Sirk 2001: 288; Zetterberg 2010: 434; Raun 2012: 101-102).

Nagu eespool mainitud, on nüüdseks arhiiviinfosüsteemis AIS kättesaadavad Rahvusarhiivi (fondi ERA.5201) jõudnud nimemuutmistoimikute ( $\mathrm{n}=91286)$ kirjeldusandmed. Need on sisestatud aga arhiivikirjelduse, mitte andmetöötluse eesmärke täites tekstina, kuid sisaldavad ka kõikide nimemuutjate eesnimesid. Säilikute tüüppealkirjade tõttu oli siinkirjutajal võimalik teha tekstist tabel, et seda statistiliselt analüüsida. Selleks kanti iga isiku eesnimi ja perekonnanimed eraldi lahtrisse.

Andmeid võrreldes selgus, et toimikuid on ka muutmistoimingute kohta, mis ei jõudnud otsuseni. Näiteks soovis 1935. aastal perekond Unujaan võtta uueks nimeks Ariste ning perekond Vänzel uueks nimeks Ventsel, kuid kummalgi seda ei võimaldatud (RA, ERA.5201.2.80202). Asjaajamistoimik on olemas, pealkirjast aga ei selgu, kas muutmisavaldus rahuldati. Selliseid toimikuid on hinnanguliselt 7500.

Kõiki nimemuutmistoimikuid selles arhiivifondis pole. Siinkirjutaja on toimikuid leidnud ka mujalt, sh üldtoimikutest (nt RA, ERA.14.2.700; RA, ERA.14.2.1262), kaitseregistrisse kandmise toimikute vahelt (RA, ERA.14.2.288) jm. Enim on puudu 1940. aastal lõpetatud toimikuid, kuna nähtavasti polnud neid veel Siseministeeriu- 
misse saadetud ja need hävisid sõja ajal. Järelikult ei saa säilinud toimikute põhjal teha täpseid järeldusi nimemuutmiste arvu kohta.

Küll aga saab toimikute andmeid kasutada ühe muutmistoiminguga seotud keskmise isikute arvu teada saamiseks. Ühes toimikus on 1-22 isiku andmed. 22 isikuga on üks (Wassikas > Heinlaid (24. XI 1926 Pärsamaa) hõlmab nelja põlvkonna esindajaid), 14 isikuga kaks, 12 isikuga 13 toimikut. Kõige enam on ühe (39 487, 43,3\% toimikutest) ning kahe (17 580, 19,3\%) isikuga toimikuid. Kokku on toimikutes 215580 isiku andmed. Kõige rohkem isikuid on kolme (41 826, 19,4\% isikutest) ja nelja $(41268,19,1 \%)$ isikuga toimikutes. Ühe toimiku keskmine isikute arv on 2,36. ${ }^{8}$ Arv on oluliselt väiksem nimemuutmise ajal keskmiseks peetud 2,5-st. Näha on ka selge langustendents aastati, arvestades toimiku algdaatumit (vt tabelit 1).

OA kirjete arvu kasutamine muutjate üldarvu teada saamiseks ei annaks täpset tulemust, kuna ühe perekonnaseisuametniku poolt samas RTL-i numbris avaldatud sama vana ja uue nimega kuulutused on sisestatud ühe kirjena. Näiteks võisid korraga nime muuta täisealised õved (ka koos peredega) ning nende nimemuutmine kajastub eraldi otsustena, kuid andmebaasis ühe kirjena. Koosmuutmisi toimus lausa suguvõsati. Näiteks leidub andmebaasi ühe kirje Vilberg > Vilbaste (4. X 1935 Kodasoo) taga 15 kuulutust 39 inimesega, kirje Laisk > Laaneväli (13. VI 1922 Hellamaa) taga on viis kuulutust 27 inimesega.

Puuduolevate kirjete hulga arvutamiseks võrreldi aastate 1935-1940 igast kvartalist ühe RTL-i numbri otsuste ning sama numbri kirjete arvu OA-s (v.a 1938. aasta IV kvartal, kus otsuste ja kirjete arv on andmete hilisema sisestuse tõttu sama). 5445 otsuse kohta oli OA-s 4818 kirjet, puuduolevate kirjete hulk erines aastati (vt tabelit 1).

Nimemuutjatest tuleb eraldada rööpnimede kaotajad ehk 477 kirjet (olenemata sellest, et nad loeti omal ajal nimemuutjate arvestusse). Tuletades OA kirjetest otsuste arvu (ilma rööpnimede kaotamisteta) ning korrutades selle iga aasta keskmise isikute arvuga otsuse kohta, saab üldtulemuseks 197 153. Kuna praeguste andmestike põhjal puudub võimalus maha arvestada kõiki rööpnimede kaotamisi, samuti neid, kes võtsid tagasi oma neiupõlvenime, andsid oma kasu- või vallaslapsele enda perekonnanime jmt, on põhjust oma perekonnanime eestistanute arvuna kasutada ümardatult 195 000, mille kaasaegne statistika ületas juba 1. jaanuariks 1940. See on ka 15000 võrra ehk 7,1\% väiksem ligi pool sajandit kasutatud arvust 210000 (nt EKK: 618).

Tabelis 1 on toodud eelnimetatud arvutused ning võrdlusandmed kaasaegse statistikaga. Autoril on õnnestunud leida vaid üks, Edgar Rajandi koostatud mustanddokument 1940. aasta kevadest, kus on toodud andmed 1939. aasta lópuni ning seda nii sooviavalduste kui ka otsuste kohta. ${ }^{9}$ Andmed pole aastati küll täpselt võrreldavad, sest otsused avaldati RTL-is viivitusega ning andmebaasis on avaldamise kuupäev. Andmeridu on seega kolm: sooviavaldused, otsused ning otsuste avaldamised.

\footnotetext{
${ }^{8}$ Täpne tulemus on 2,36161. Üldarvu arvestamisel tabelis 1 on lähtutud iga aasta keskmisest eraldi, mujal aga kõikide aastate keskmisest.

${ }^{9}$ Dokument „Perekonnanimede ja nimede eestistamise käik aastate järgi” kaustas „Nimede Eestistamise Keskbüroo mitmesugused materjalid”, Edgar Rajandi perekonna valduses. Tänan siinkohal Rajandi järeltulijaid Merike Kallast ja Maiu Pevkurit materjalide kasutamise võimaluse eest.
} 
Erinevus arvutusliku ja tegeliku tulemuse vahel perioodi 1920-1934 kohta on selgitatav sellega, et arvutuslikust tulemusest on välja jäetud rööpnimede kaotamise otsused, mis mõjutavad selle perioodi lõpptulemust oluliselt. Aastail 1935-1936 on näha sooviavalduste palju suurem hulk võrreldes muutmisotsustega ning on loomulik, et just sel põhjusel kasutati avalikkuses neist esimest arvu argumendina kõhklejate ärgitamiseks. Alles hiljem hakati avaldama tõepärasemat otsuste statistikat. Siiski jätkus isikute arvu saamiseks otsuste üldarvu korrutamine 2,5-ga.

Tabel 1. Nimemuutmiste arvutuslik üldarv ja võrdlus 1940. a-ni tehtud statistikaga.

\begin{tabular}{|c|c|c|c|c|c|c|c|c|}
\hline \multirow[t]{2}{*}{ Aasta(d) } & \multirow{2}{*}{$\begin{array}{l}\text { Kirjete } \\
\text { arv } \\
\text { OA-s }\end{array}$} & \multirow{2}{*}{$\begin{array}{l}\text { Kirjeid } \\
\text { ilma rööp- } \\
\text { nimede } \\
\text { kaotami- } \\
\text { seta }\end{array}$} & \multirow{2}{*}{$\begin{array}{l}\text { Hinnan- } \\
\text { guliselt } \\
\text { puudu- } \\
\text { vaid } \\
\text { kirjeid }\end{array}$} & \multirow[t]{2}{*}{$\begin{array}{l}\text { Tõenäoline } \\
\text { otsuste arv }\end{array}$} & \multirow{2}{*}{$\begin{array}{l}\text { Ühe } \\
\text { muutmis- } \\
\text { toimiku } \\
\text { keskmine } \\
\text { isikute arv }\end{array}$} & \multirow{2}{*}{$\begin{array}{l}\text { Nime- } \\
\text { muutjate } \\
\text { arvutuslik } \\
\text { hulk }\end{array}$} & \multicolumn{2}{|c|}{$\begin{array}{l}\text { 1940. aastani } \\
\text { peetud statistika }\end{array}$} \\
\hline & & & & & & & \begin{tabular}{|l|} 
Soovi- \\
avaldusi \\
x 2,5 \\
\end{tabular} & $\begin{array}{l}\text { Otsuseid } \\
\times 2,5\end{array}$ \\
\hline $1920-1934$ & 1053 & 845 & $11,4 \%$ & 954 & 2,16 & 2060 & 2672 & 2672 \\
\hline 1935 & 10544 & 10487 & $10,8 \%$ & 11760 & 2,57 & 30223 & 34196 & $30000^{10}$ \\
\hline 1936 & 21832 & 21804 & $13,1 \%$ & 25086 & 2,48 & 62214 & 78164 & 62753 \\
\hline 1937 & 18517 & 18492 & $12,1 \%$ & 21046 & 2,24 & 47144 & 43069 & 50518 \\
\hline 1938 & 12901 & 12855 & $9,7 \%$ & $13963^{11}$ & 2,14 & 29881 & 30225 & 35845 \\
\hline 1939 & 5937 & 5877 & $11,9 \%$ & 6668 & 2,02 & 13470 & 15313 & 15740 \\
\hline 1940 & 5433 & 5409 & $9,6 \%$ & 5985 & 2,00 & 11971 & - & \\
\hline $1942-1944$ & 147 & 118 & $0,0 \%$ & $118^{11}$ & 1,61 & 190 & - & 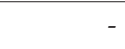 \\
\hline $\begin{array}{l}\text { Kokku/ } \\
\text { keskmine }\end{array}$ & 76364 & 75887 & $11,7 \%$ & 85581 & 2,36 & 197153 & 203639 & 197528 \\
\hline
\end{tabular}

Nimemuutmiste analüüsil on võimalik lähtuda ühelt poolt nimevahetajate arvust, teiselt poolt vahetatud ja võetud nimede arvust. Keeleliseks analüüsiks on enamasti otstarbekam näiteks 52 muutmiskorra Steinberg > Kivimäe käsitlemine ühe muutusena. Seda on rakendatud siin töös soovitusnimestiku kasutuse analüüsil. Nimede esitähtede analüüsil on aga olulisem vaadelda muutmiste arvu ehk mitu korda muudeti $k$-algulised nimed samuti $k$-algulisteks, mitte aga seda, mitu $k$-algulist nime muudeti samuti $k$-alguliseks. Muutmiste arvust on allpool lähtutud esitähtede, nimepikkuste ja ainukordsuse analüüsil.

\section{Soovitusnimestik „Eesti nimi" ja võetud nimed}

Eestistamise algusest saadik üritasid algul keeleteadlased, hiljem ka riik suunata uue nime valikut. Selleks koostati soovitusnimestikke, loodi kaitseregister ning piirati laialt levinud nimede võtmist. Siinses peatükis on vaadeldud 1935. aasta soovitusnimestiku „Eesti nimi” sisu ning selle mõju võetud nimede valikule.

\footnotetext{
${ }^{10}$ Ligikaudne, täpne statistika puudus.

${ }^{11}$ 1938. aasta IV kvartali ja aastate 1942-1944 otsuste ja kirjete arv on vastavuses, seega pole nendele andmetele puuduvate kirjete hulka lisatud.
} 
Üks seadustes loetletud nimevahetuse võimalikke põhjuseid oli alates 1930. aastast nime lai levik. Siseminister andis 14. detsembril 1934 välja laialt tarvitusel olevate perekonnanimede määruse (RT 1934, 107, 842) 188 eestipärase nimega, mida ei tohtinud endale uueks nimeks võtta. Mitte-eestipäraseid nimesid ei tohtinud eestlased nagunii võtta ning teiste rahvuste nimevaramuga tegelemist eesmärgiks ei seatud. Nimekirja kanti tol hetkel nimed, mida esines Tallinnas ja Tartus enam kui sajal kandjal (Lepp 1936: 265).

Loetelu täiendati 1935. aastal 19 nimega (RT 1935, 98, 806) ja 1938. aastal 82 nimega (RT 1938, 97, 840). Kokku oli nimekirjas 1938. aastaks 289 nime. Samas oli üle 100 kandjaga eestipäraseid nimesid 1934. aastal 1127 ja juba 1936. aastal leiti, et keelunimekirja tuleb täiendada, sest laialt levinud nimesid võeti agaralt endale uueks nimeks (Lepp 1936: 265). Põhjusena, miks nimekirja ei täiendatud, võib näha soovi mitte takistada kampaania käiku ja samuti lootmist soovitusnimestikule.

Esimene soovitusnimestik oli 1921. aastal ilmunud „15.000 uut sugunime” (US 1921), mida kasutati nimepanekul Petserimaal ja Narvatagusel ning mida tõenäoliselt sel põhjusel ning ka maitse muutumise tõttu peeti poolteist aastakümmet hiljem vananenuks. See sisaldab ka üsna palju ebaõnnestunud nimesid (Karvastik, Pihkupere, Tusaste, Õngekalju, Õudusmaa, Üüritar). 1935. aastal hinnati, et see oli „erakordse kiirusega koostatud ja on olnud ainult „hädalist tarvidust rahuldama ruttav katse", [---] sisaldades tunduval määral vähesoovitavat nimeainestikku” (EN 1935: 26). Paraku on väljaanne trükitehniliselt kesise kvaliteediga (mimeograafiline paljundus) ning seetõttu pole ka selle tärktuvastus arvutianalüüsiks kasutatav.

1935. aastal ilmus valimik „4000 uut nime. Kuidas leida uut nime” (UN 1935). Sellest avalik tärktuvastusversioon puudub, kuid ka selle olemasolul poleks see põhjaliku eeltöötluseta kasutatav, kuna seal on eri variandid esitatud liitekohta märkimata: Avu(vur), Paiga(gaste), Palmik(vik). Raamat ilmus umbes 20. jaanuaril 1935, sest päev hiljem kirjutas sellest kirjastaja ajaleht Oma Maa. Eestistamist oli ajalehe arvates rahva väitel pidurdanud nimemoodustusjuhiste puudumine, sest „tahetakse ju, et nimi oleks ilusakõlaline ja sobiv”, ning just neid uus brošüür pakkuvat (Põhjaklane 1935). Raamat ilmus Viljandis ning seal oli sellel kahtlemata oma mõju, mida on edaspidi põhjust uurida. 9. märtsil 1935 kirjutas Postimees: „Tartlased ja tallinlased ammu juba koostavad kahasse uute eesti perekonnanimede valikut: Tartlased teevad nimed, Tallinn maksab kinni kulud ja kirjad. Viljandlastel aga on oma „4000 uut nime" juba ammu valmis. [---] See raamat on igal viljandlasel taskus." (Andermann 1935)

Tartlaste ja tallinlaste nimetatud koostööna ilmus 15. märtsi paiku 1935 (RA, ERA.1093.1.219, 1 7) Akadeemilise Emakeele Seltsi toimetiste sarjas Julius Mägiste ja Elmar Elisto toimetatud väljaanne „Eesti nimi. Valik uusi perekonnanimesid” (EN 1935). Nimestiku tärktuvastusversiooni kasutades avati analüüsi jaoks kõik välja pakutud variandid (Saulep, -i > Saulep ja Saulepi, Salukan|d, -nu > Salukand ja Salukannu), koos nendega selgus nimekirjas olevat 15595 nime. Kõige pikem välja pakutud nimi on 12-täheline (Haavistniidu), 11-tähelisi on juba 21 (Kloostremaa, Kaasikniidu) ning 10-tähelisi 578. Soovitatud nimede keskmine pikkus on 7,3 tähte 
(kvartiilid ${ }^{12}$ : $\mathrm{Q}_{1}=6, \mathrm{Q}_{2}=7, \mathrm{Q}_{3}=8$ ). Kuni seitsme tähe pikkuseid nimesid on 52,8\% $(\mathrm{n}=8239)$. Vähemalt 10 -tähelised nimed $(\mathrm{n}=600)$ moodustavad suhteliselt suure osa (3,9\%). Esitähtedena on kasutatud 20 tähte, eesti omasõnade tähtedest on välja jäetud $b, d, g$. Kõige enam $(17,8 \%)$ on välja pakutud $k$-algulisi nimesid $(\mathrm{n}=2792)$, järgnevad $p$-algulised $(\mathrm{n}=1500,9,6 \%)$.

Analüüsiks kõrvutati soovitusnimestiku nimesid alates 16. aprillist 1935 ilmunud muutmisotsuste nimedega. Sooviavaldus pidi olema ilmunud vähemalt kuu aega varem ehk hiljemalt 15. märtsil 1935, seega enne soovitusnimestiku trükkimist. Tegelikult ilmusid ka muutmisotsused mõnevõrra hiljem. Näiteks 18. märtsil 1935 tehtud muutmisotsus Ende > Sammalkivi ilmus alles 12. aprillil. Nimi Sammalkivi on soovitusnimestikus, kuid kuna sooviavaldus ilmus juba 16. veebruaril, ei saanud nimi olla sealt võetud.

Kuni 15. aprillini 1935 võeti kokku 205 korral 151 nime, mis esinevad samuti soovitusnimestikus. Tegu on sageli kohanimedega (Aimla, Maidla, Osula), ste-lõpuliste nimedega (Aunaste, Marguste, Tõniste), loodussõnavarast tuletatud liht- (Kalle, Lehis, Luide) ja liitnimedega (Mäepõld, Póldmaa), mille väljamõtlemiseks ei olnud vaja soovitusnimestikku. Kõikidest sama perioodi muutmiskordadest moodustavad need $9 \%$.

Alates 16. aprillist 1935 võeti kokku 73591 korral 15397 erinevat uut nime. Neist 30,5\% ( $\mathrm{n}=4695)$ esinevad soovitusnimestikus. Kuna vaadeldud perioodil võetud nimede hulk on üsna lähedane soovitusnimekirja nimede hulgaga, on sarnane ka vastupidine näitaja: nimekirjas olevatest nimedest läks kasutusele 30,1\%.

Nimestikust võetud nimede keskmine pikkus on 6,9 tähte ehk välja pakututest veidi vähem, kvartiilid aga kattuvad $\left(\mathrm{Q}_{1}=6, \mathrm{Q}_{2}=7, \mathrm{Q}_{3}=8\right)$. Siiski moodustavad kuni seitsme tähe pikkused võetud nimed $(\mathrm{n}=3131) 66,2 \%$ ehk soovitatutest palju enam. Üle 10-tähelisi nimesid ei võetud, 10-tähelisi võeti 77 korral (1,6\%). Seega eelistati soovitusnimestikust võtta veidi lühemaid nimesid (vt joonist 2).

Kõikide algustähtedega nimesid võeti soovitusnimestikust ka kasutusele, kõige enam välja pakutuga sarnaselt $k$-algulisi $(\mathrm{n}=676,14,3 \%)$, teisena aga $l$-algulisi $(\mathrm{n}=$ 449, 9,5\%), p-algulised jäid kolmandaks ( $\mathrm{n}=411,8,7 \%$ ). Siintoodud analüüs põhineb võetud nimede koondnimekirjal, kus iga nimi esineb vaid korra. Muutmiskordi arvestades on pilt veelgi ilmekam.

Soovitusnimestikuga kattuvaid nimesid võeti 27263 korral ehk 37\%-l muutmistest. Üle 100 korra võetud nimed on tabelis 2 . Üle 50 korra võeti 72 nime, ühel korral 1741 nime (37\% nimede koguvalikust).

Muutmiskordi arvestades on nimede keskmine pikkus ikka 6,9, samad on ka kvartiilid. Nimede esitähtede järgi on esikohal endiselt $k$-algulised nimed $(\mathrm{n}=3580$, $13,1 \%)$, kuid teisel kohal on $r$-algulised $(\mathrm{n}=2980,10,9 \%)$, mis soovitustes on viiendal (8\%) ning võetud nimede loetelus neljandal $(8,5 \%)$ kohal. Kolmandal on muutmiskordi arvestades $l$-algulised $(\mathrm{n}=2640,9,7 \%)$. Seda selgitab esiteks üksikute $r$-alguliste nimede populaarsus (vt tabelit 2) ning teiseks populaarsete sõnadega raud, rand

\footnotetext{
${ }^{12}$ Kvartiilid on tunnuse väärtused variatsioonireal, mis jagavad variatsioonirea neljaks ligikaudu võrdseks osaks. Näiteks $Q_{1}$ on tunnuse väärtus, millest väiksemaid või võrdseid tunnuseid on ligikaudu $25 \%$.
} 
ja rehi $\sim$ rei algavate nimede suur hulk (Ran- 665, Raud- Raua- 168, Rei- 528) ning $r$-alguliste nimede tugevana tajutav kõla. Võrdluse soovitusnimestiku, sealt kasutusele võetud nimede ning kõikide võetud nimede esitähtede kohta annab joonis 1.

Soovitusnimestiku kasutamist on põnev vaadelda ka omavalitsuseti. Nimestikuga kattuvate uute nimede osakaal neis on $0-83 \%$. Ükski nimi ei kattu viies omavalitsuses, kuid kõigis nendes on nimemuutmiste koguarv ühest kuueni ning nimestikuga mittekattuvus võib olla juhus ega näita nimestiku teadlikku vältimist. Küll aga võib väita, et nimestikku peaaegu ei kasutatud suuremate nimemuutmiste arvuga Kärgula (1 nimi 12-st ehk 8\%), Taheva (3/28 ehk 11\%), Kuusalu (5/45 ehk 11\%) ega Muhu (1/9 ehk 11\%) vallas. Nimestiku kasutamist on näha selgemini, kuna tipus on muutmiste arvud suuremad: Põdrala (7/10 ehk 70\%), Maasi (80/107 ehk 75\%), Puhja (12/15 ehk 80\%), Pöide (13/16 ehk 81\%) ja Kalda (19/23 ehk 83\%) vald. Enamikus omavalitsustes kasutati nimestikku kolmandiku jagu $\left(\mathrm{Q}_{1}=32 \%, \mathrm{Q}_{2}=37 \%, \mathrm{Q}_{3}=43 \%\right)$.

Aastate lõikes on näha nimestiku mõju kerget suurenemist. Kui 1935. aastal võeti soovitusnimestikus esinev nimi 30,5\%-1 kõigist muutmiskordadest, siis 1939. aastal oli protsent juba 39,2 (vt joonist 3). Tõenäoliselt muutus vähelevinud nime soovijal sellise nime leidmine pidevalt raskemaks ning soovitusnimekirja abi tuli kasutada rohkem kui kampaania algusaastal.

Soovitusnimestiku „Eesti nimi” koostanud keeleteadlased Julius Mägiste ja Elmar Elisto olid seega pärast nimestiku ilmumist 37\% ehk umbes 65000 nimemuutja „ristiisad”, nagu seda öeldi Villem Ernitsa ja Samuel Sommeri kohta Petserimaa ja Narvataguse nimepanekul. Viimati mainitud protsess oli küll pigem suunav ja eestistamine rohkem vabatahtlik, kuid nagu näha, oli soovitusnimestiku abi kasutamine massiline. Kindlasti ei võtnud kõik soovitusnimestikus leiduva nime saanud seda endale otse raamatust, vaid võisid seda teha sugulaste, tuttavate, kohanime või ajakirjandusest loetu eeskujul, kuid nimestiku tähtsus kogu protsessis on ilmselge.

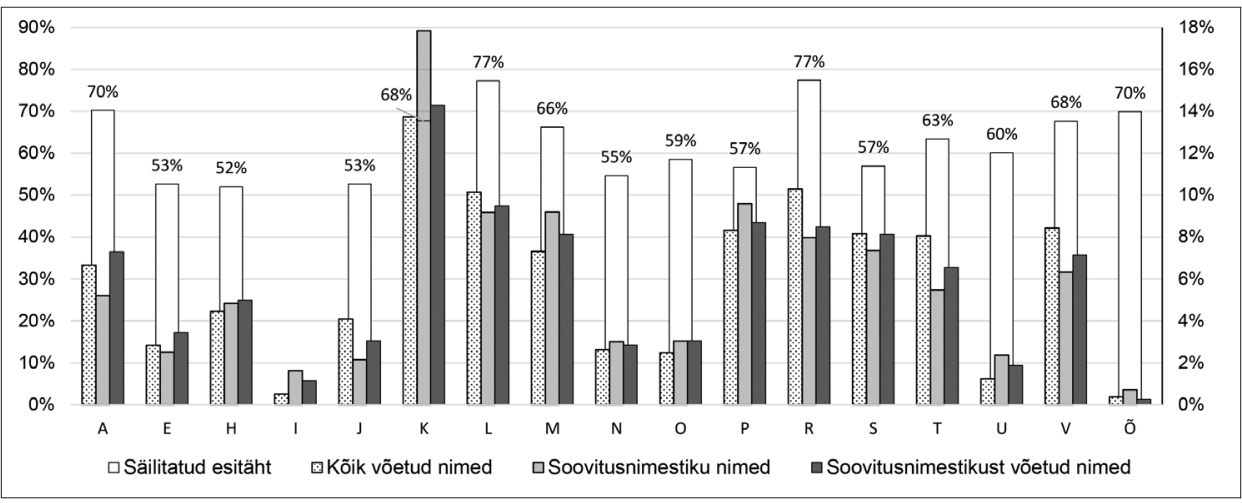

Joonis 1. Esitähtede säilitamine nimemuutmisel (primaarteljel) ning soovitusnimestiku "Eesti nimi", sealt kasutusele võetud nimede ja kõikide võetud nimede esitähtede osakaal (sekundaarteljel). Välja on jäetud esitähed, millega algavaid nimesid võeti alla 100 korra (b, $d, f, g, \breve{s}, z, w, a ̈$, ö, ü), ning need, mida säilitati nimemuutmisel alla $50 \%$ juhtudest. 


\section{Võetud nimede esitähed, pikkus ja ainukordsus}

Siinses peatükis uuritakse, kui levinud oli nime esitähe säilitamine, samuti milline oli kõige „parema” pikkusega nimi ning kas eelistati nimesid, mida võtsid paljud, või neid, mida kellelgi teisel polnud.

Aadu Must (2000: 64) on oma loodud andmebaasi põhjal toonud üldistuse, et umbes pooltel kordadel oli u uel nimel vanaga sama esitäht. Selgub aga, et alliteratsiooni ja assonantsi kasutamine oli nimemuutmiste puhul täheti üsna erinev. 75887 nimemuutmisest kattub uue nime esitäht vanaga 43064 korral (56,8\%). Üsna võrdne on jagunemine alliteratsiooni $(56,4 \%)$ ja assonantsi $(59,3 \%)$ vahel. Enim on sama esitähe säilitanud $r$ - $(77,4 \%), l$ - (77,3\%), $a$ - (70,2\%) ja $\tilde{o}$-algulised $(69,9 \%)$ nimed, kõige vähem eesti omasõnade tähtedest aga $b$ - $(0,1 \%), d-(0,2 \%)$ ja $\ddot{o}$-algulised (13,3\%), nendega kaasneb ka võõrnimede täht $f(0,2 \%)$. Alla $50 \%$ on kattuvus veel vaid esitähtedel $i$, $\ddot{a}$ ja $\ddot{u}$.

Kronoloogiliselt analüüsides on näha selge suund esitähe säilitamisele: kui 1935. aastal kattus see 52,3\%-1 juhtudest, siis 1940. aastal 59,9\% ning tõus on ühe väikese erandiga (1939. a) pidev (vt joonist 3). Veelgi ilmekam on populaarseima säilitatava $r$-tähe kasv samadel aastatel 74,4\%-lt 82,8 protsendini, samuti ühe erandiga (1939. a) pidevas tõusus.

Piirkonniti on erinevaid tendentse. Olgu siinkohal toodud vaid Tallinna (60,9\%) üle keskmise ning Tartu (54,5\%) ja Narva (51,3\%) alla keskmise näitajad esitähe säilitamisel.

Olenemata vanast nimest ja soovitusnimestiku eeskujuna kasutamisest, võeti uueks nimeks kõige enam kordi $k$ - $(13,7 \%), r$ - $(10,3)$ ja $l$-algulisi $(10,2 \%)$ nimesid. Kokku moodustavad need üle kolmandiku toimunud nimemuutmistest. Joonisel 1 on näidatud esitähed, mida säilitati üle 50\%-1 juhtudest, samuti enim kasutatud esitähtede osakaal.

P ik ku s e poolest eelistas 25\% muutjatest endale võtta 7-tähelise, 23,4\% 6-tähelise ja 20,6\% 8-tähelise nime (vt joonist 2). Need kolm hõlmavad 69,1\% kõikidest nimemuutmistest. Pikimad olid mitte-eesti nimed Kessler Rossillon en Bugey (26 tähte), Popoff-Beboutoff (16) ja Bever-Bodenburg (15), eesti nimedest Tofer-Toriveri (14). Kõiki neid ei tuleks lugeda mitte sisuliseks, vaid pelgalt vormiliseks muutmiseks, kuna osa nimest oli varemgi kasutusel. Pikim uus eesti nimi oli Tammesaarväli (13 tähte, võeti ühel korral), lühima nimega olid viis nimemuutmist (nimed Ao ja $\mathrm{Oa})$.

Monofüleetilisi ehk a in ut ek ke lis i n i mesid on keeruline tuvastada, kuna võtmise kordade arv seda ei näita. Näiteks võeti kahel korral nimi Kernumees (Amblas ja Tallinnas), kuid et selle võtsid isa ja poeg perega (endine nimi Kirnmann), on nimi ainutekkeline. Nime Surve võeti samuti kahel korral (Kaiu ja Haljala vallas), kuid juba muudetavad nimed (Klemmer ja Seks) näitavad, et nimi Surve on polüfüleetiline ehk mitmiktekkeline. Seetõttu saab ilma mikroanalüüsita ainutekkelisteks pidada vaid ühel korral võetud nimesid, mida on 7361 (9,7\% kõikidest muutmistest), nende osakaal aasta-aastalt kergelt tõusis (vt joonist 3). 42 omavalitsuses ei võetud ühtegi ainutekkelist nime. Ainutekkeliste nimede suure hulgaga paistavad silma 
Petserimaa omavalitsused. Neist, kus on üldse võetud vähemalt kümme nime, ongi ainutekkeliste nimede poolest esikohal Roodva (ainutekkelisi 6 ehk 28,6\%) ja Saatse vald (4 ehk 28,6\%) Petserimaal ning Vasknarva vald (4 ehk 28,6\%) Virumaal.

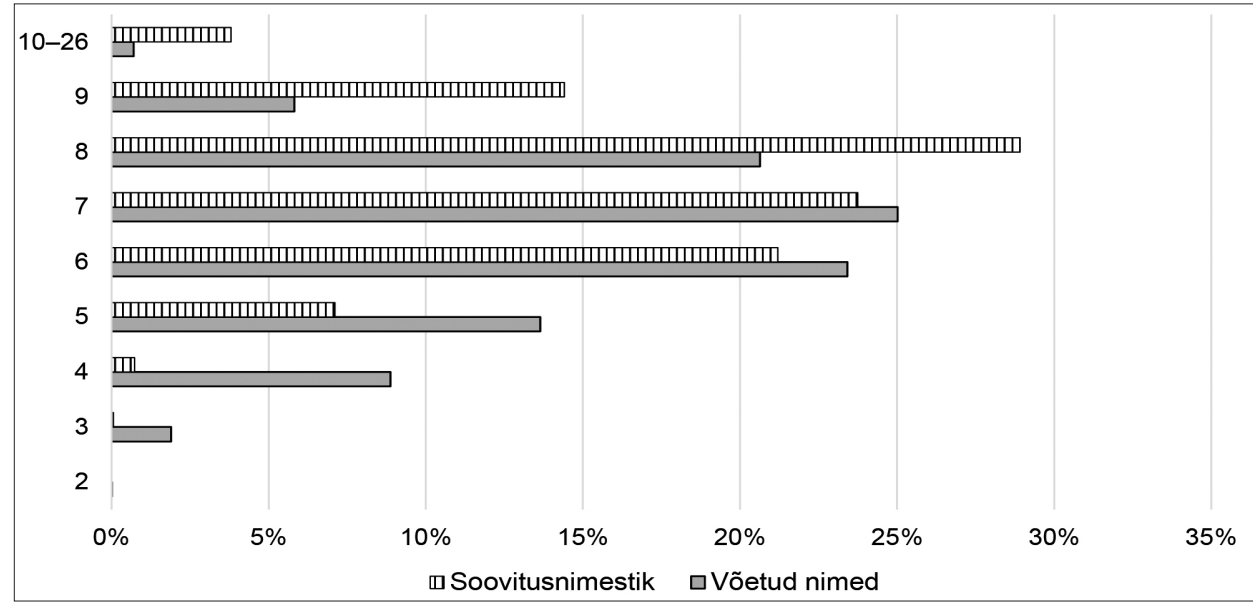

Joonis 2. Võetud nimede ja soovitusnimestiku „Eesti nimi” nimede pikkus tähtedes.

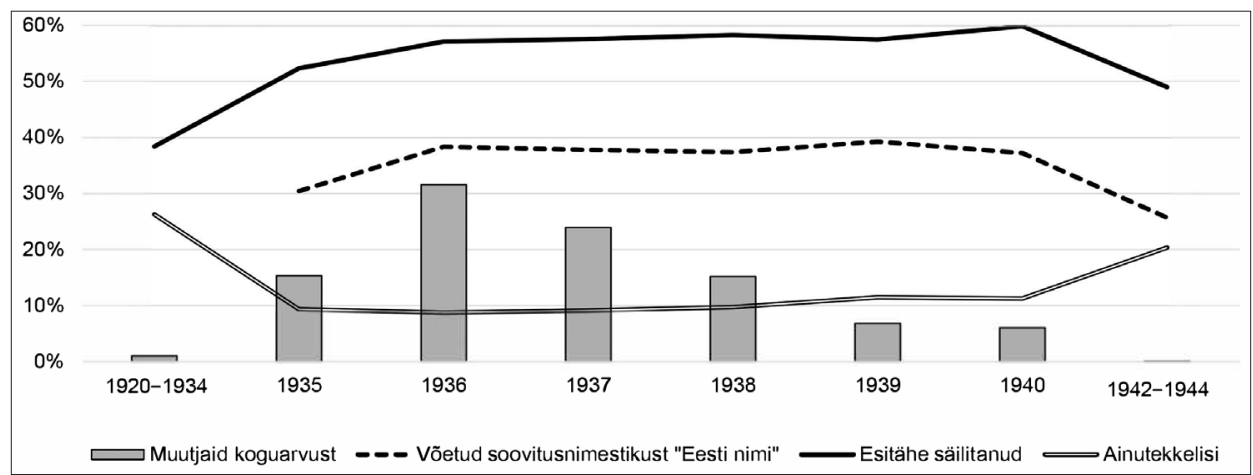

Joonis 3. Nimemuutjate koguarvu, soovitusnimestiku kasutamise, esitähe säilitamise ning ainutekkeliste nimede dünaamika.

Nimede ja nende võtjate kohta kehtib peaaegu Pareto reegel: 73\% nimemuutjatest kasutas ära $22 \%$ võetud nimede valikust. Seetõttu olgu toodud ka populaarseimate võetud nimede edetabel (tabel 2). Osa neist esineb ka soovitusnimestikus, kuid neid on võetud mõnel korral ka enne nimestiku ilmumist. Nimede muutmise plahvatuslik kasv ja soovitusnimestikus esinemine ei ole alati seotud, kuna mõlemad langesid ajaliselt kokku. Eeldatavalt on aga just soovitusnimestikust alguse saanud osa populaarseimatest nimedest.

Muutmise tippajast 1935-1940 erinevad varasema ja hilisema perioodi nimevalik oluliselt. Mõlemal perioodil on ainutekkeliste nimede hulk suurem, esitähe säilitamine harvem ning Saksa ajal langes ka soovitusnimestiku kasutamine (vt joonist 3). 
Tabel 2. Populaarseimad eestistamisel võetud nimed. Allajoonitud esinevad soovitusnimestikus, tärniga tähistatud laialt levinud nimede keelunimestikus. Esimene number näitab muutmiskordi, teine isikute arvutuslikku hulka, kolmas muutmiskordi, kui palju soovitusnimestikus olevat nime võeti enne nimestiku ilmumist.

\begin{tabular}{|c|c|c|}
\hline 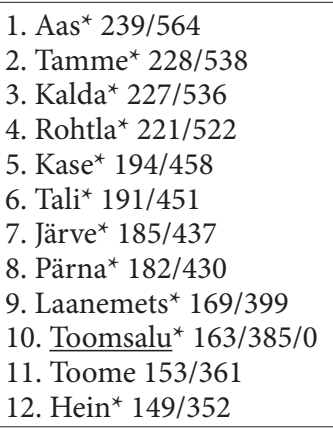 & 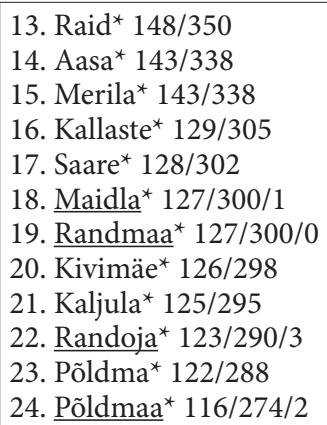 & $\begin{array}{l}\text { 25. } \underline{\text { Soosalu }}^{*} 111 / 262 / 3 \\
\text { 26. } \text { Raidma }^{*} 108 / 255 / 2 \\
\text { 27. } \text { Lillemets }_{108 / 255 / 0} \\
\text { 28. } \text { Ojala } 107 / 253 / 0 \\
\text { 29. Ojaste } 107 / 253 \\
\text { 30. Vahtra } \\
\text { 31. } 107 / 253 \\
\text { 3einla } 104 / 246 / 1 \\
\text { 33. Randma } \text { Männiste }^{*} \text { 103/243 } \\
\text { 34. } \text { Kaldma }^{*} 101 / 239 / 4 \\
\text { 100/236/0 }\end{array}$ \\
\hline
\end{tabular}

\section{Kokkuvõtteks}

Artiklis analüüsitakse 1990. aastate oskuse ja tollaste nimeuurimise teadmiste järgi koostatud nimede eestistamise andmebaasi ning antakse ülevaade selle kasutamise probleemidest. Kuigi andmebaas oleks analüüsitav ka oma algkujul, tuli parema tulemuse saamiseks selle andmestikku korrastada.

Täpsema tulemuse saamiseks kõrvutati erinevaid andmestikke. Nimemuutjate üldarvu arvutamisel olid aluseks nimemuutmistoimikute kirjeldusandmed Rahvusarhiivis, mille põhjal aastate kaupa arvutatud keskmine isikute arv ühes toimikus ja seega onomastika andmebaasi ühes kirjes võimaldas täpsustada nimemuutjate üldarvu.Viimane osutus seni kirjanduses käibel olevast üle 7\% väiksemaks: 210000 asemel umbes 195 000. Omaaegne lõpetamata statistika ning seal toodud muutumatu arvutusalus (2,5 isikut muutmise kohta) olid ülearu paisutanud muutjate hinnangulist arvu. Samuti arvestati siin artiklis esmakordselt rööpnimede kaotamist, mida ei saa pidada nimede muutmiseks, rääkimata eestistamisest.

1935. aastal ilmunud soovitusnimestikus „Eesti nimi” leiduvate nimede võrdlus sellest ajast alates kasutusele võetud nimedega näitab nimestiku massilist kasutust, mis aasta-aastalt suurenes, erinedes samas omavalitsuseti, ulatudes 83 protsendini Petserimaal Kalda vallas. Uueks nimeks võetud nimede koondvalikust $30,5 \%$ kattus soovitusnimestiku nimedega, olles sageli, kuid kindlasti mitte alati, ka sealt võetud. Muutmiskordi arvestades võeti nimi nimestikust lausa 37\%-1 kordadest. Nimestikus välja pakutud 15595 nimest võeti kasutusele 30,2\%, eelistades seal välja pakutud keskmisega (7,3 tähte) võrreldes lühemaid nimesid (6,9 tähte) ning välja pakutuga võrreldes suhteliselt rohkem $r$ - ja $l$-algulisi. Absoluutarvu poolest olid esikohal $k$-algulised nii välja pakutute kui ka võetute hulgas.

Võetud nimedest kattub esitäht vana nimega 56,8\%-1 kordadest. Enim on esitähe säilitanud $r$ - $(77,4 \%)$ ja $l$-algulised $(77,3 \%)$ nimed, alla poole kordadest on säilinud esitähed $b, d, f, i, \ddot{a}, \ddot{o}$ ja $\ddot{u}$. Esitähe säilitamise tendents kasvas aasta-aastalt. 
69\% võttis endale 6-8-tähelise nime, sh veerand muutjatest võttis endale seitsmetähelise nime. Iseloomulik näide esitähe säilitamisest ning uue, $k$-algulise ja seitsmetähelise nime võtmisest on muutus Kakason > Kaljula.

Ainutekkelisi ehk ühel korral võetud nimesid oli 9,7\%, enamikus Petserimaa valdadest võeti aga neid eriti palju, kõige enam Roodva ja Saatse vallas (mõlemas 28,6\%). $73 \%$ nimemuutjatest kasutas ära $22 \%$ võetud nimede valikust.

Edaspidi oleks võimalik analüüsida soovitusnimestikes välja pakutud ja tegelikult võetud nimede keelelist külge (siin tehtud automaatse morfoloogilise analüüsi katsed eesti keele sõnavara baasil ${ }^{13}$ andsid selleks lootust, kuid jäid välja artikli mahu tõttu), esteetiliselt motiveeritud nimemuutusi (Junn > Vetesina), sugulussuhetel tuginevaid nimemuutusi (varem eksisteerinud nimede taaskasutamist), perekonna- ja talunimede seost (võrdluseks näiteks 1938. aasta katastriüksuste andmebaas), geograafilis-kronoloogilist dünaamikat (millised olid algul mahajäänud piirkonnad), võetud nimede geograafilist levikut (kus võeti enim kõige levinumaid nimesid, kas ülilevinud kalju- ja ranna-algulised jm merega seotud nimesid võtsid mereäärsed elanikud), nimede eeskuju (nime levima hakkamine raadioesinemiste järel, nt Johannes Silveti eeskuju), vanade ja uute nimede pikkuse seost, muutmiste sesoonsust, kampaaniate mõju jne.

Nimede eestistamise suure andmebaasi kasutusvõimalusi on palju ning olemasolevate naaberandmestike ning digihumanitaarsete oskuste ja võimaluste arenedes lisandub neid veelgi.

\section{VEEBIVARAD}

Haudi $=$ Haudi. Kalmistute register. https://www.kalmistud.ee

OA = Onomastika andmebaas. Aadu Musta poolt 1995-1999 koostatud perekonnanimede paneku ja eestistamise andmed. http://www.ra.ee/apps/onomastika/. Täiendanud Fred Puss alates 2000. Fred Pussi valduses.

\section{ARHIIVIALLIKAD}

\section{Rahvusarhiiv (RA)}

ERA.14.2.288. Siseministeerium. Kirjavahetus perekonnanimede kaitseregistrisse kandmise kohta. 1936-1937.

ERA.14.2.369. Siseministeerium. Kirjavahetus Akadeemilise Emakeele Seltsiga ja Nimede Eestistamise Liiduga. Statistilisi andmeid nimede eestistamise kohta. 1937-1938.

ERA.14.2.700. Siseministeerium. Kirjavahetus asutuste ja isikutega perekonnanimede muutmise kohta. 1939-1940.

ERA.14.2.1262. Siseministeerium. Kirjavahetus perekonnaseisuametnike ja isikutega perekonnanimede ja nende muutmise küsimuses. 1940.

ERA.1068.1.1. Nimede Eestistamise Keskbüroo. Väljavõtted saabunud kirjadest ja statistilised tabelid perekonnanimede eestistamise kohta. 1939-1940.

\footnotetext{
${ }^{13}$ Nende eest tänab autor Eesti Keele Instituudi vanemarvutilingvisti Ahti Lohku.
} 
ERA.1093.1.219. Informatsiooni keskus. Kirjavahetus nimede eestistamise ja Eesti lippude levitamise kohta. 1934-1936.

ERA.5201.2.47594b. Siseministeeriumi perekonnaarhiivi dokumentide kollektsioon. Julia-Pauline Buschkov perekonnanime muutmine Männits. 1944.

ERA.5201.2.47594d. Siseministeeriumi perekonnaarhiivi dokumentide kollektsioon. Gretchen-Sigrid Kommusaar perekonnanime muutmine Poola. 1944.

ERA.5201.2.80202. Siseministeeriumi perekonnaarhiivi dokumentide kollektsioon. Karl, Olga Ventsel (Vänzel) perekonnanime muutmine Ventsel; Elmar, Hilda-Marie Unujaan (Unojan, Unnojan) perekonnanime muutmine Ariste. 1935-1936.

\section{KIRJANDUS}

Andermann 1935. Bussiga Viljandisse. - Postimees 9. III, nr 67.

Angelus, Oskar 1971. Die Estisierung der Namen in Estland. - Jahrbuch des baltischen Deutschtums, kd XIX (1972), lk 90-97.

ArA 1971. Kui eestlane muutis nime. Fakte sellest aktsioonist. - Eesti Päevaleht = Estniska Dagbladet 13. XI, nr 90, lk 10.

AT $=$ Ametlik Teataja. 1941-1944.

AT III = Ametlik Teataja. III osa. 1941-1944.

EE 1994 = Eesti entsüklopeedia. Kd 7 (Nõuk-rah). Tallinn: Eesti Entsüklopeediakirjastus.

EE 2003 = Eesti entsüklopeedia. Kd 12. Eesti (A-Ü). Tallinn: Eesti Entsüklopeediakirjastus.

EEN 1921 = Eestlasele eesti nimi. (Akadeemilise Emakeele Seltsi toimetused II.) Tartu: Akadeemiline Emakeele Selts.

EKK = Mati Erelt, Tiiu Erelt, Kristiina Ross, Eesti keele käsiraamat. Uuendatud väljaanne. Tallinn: Eesti Keele Instituut, Eesti Keele Sihtasutus, 2020.

Elisto, Elmar 1938. Nimede eestistamisest Eestis. - Omariikluse süvendamisel. Ü. S. Raimla koguteos. Peatoim Jüri Parijõgi. Tartu: Ü. S. Raimla kirjastus, lk 47-62.

Elisto, Elmar 1976. Õigest keelest, tervest meelest. Keelelisi küsimusi II. Tallinn: Eesti Raamat.

EN 1935 = Eesti nimi. Valik uusi perekonnanimesid. Toim Julius Mägiste ja Elmar Elisto. (Akadeemilise Emakeele Seltsi toimetised XXVII.) Tartu: Akadeemiline Emakeele Selts.

ENE 1974 = Eesti nõukogude entsüklopeedia. Kd 6 (Pais-rumo). Tallinn: Valgus.

ENSV T = Eesti NSV Teataja. 1940-1960.

ENSV TL = Eesti NSV Teataja Lisa. 1940-1957.

Glavlit 1948 = ENSV Kirjandus- ja Kirjastusasjade Peavalitsuse ülema käskkirjadega kõrvaldatavate eestikeelsete raamatute üldnimestik (1940-1947). Tallinn: RK Poliitiline kirjandus.

Glavlit 1963 = Raamatukogudest ja antikvariaatidest kõrvaldamisele kuuluvate kodanlikul ja okupatsiooni ajal Eestis ilmunud väljaannete koondnimekiri. II osa. Tallinn: s.n.

Grönberg, Artur 1985. Eesti Üliõpilaste Seltsi ajalugu. II: Iseseisvuse eelvõitluses (1906-1917). Omariikluse saavutustes (1918-1940). Montreal: Eesti Üliõpilaste Seltsi Vanematekogu kirjastus.

Henno, Kairit 2001. Emakeele Selts nimede eestistamise käivitajana. - Keel ja Kirjandus, nr 2, lk 73-79. 
Henno, Kairit 2002. Riiklikust isikunimekorraldusest aastatel 1918-1940. - Õiguskeel, nr 4, lk 33-42.

Karjahärm, Toomas; Sirk, Väino 2001. Vaim ja võim. Eesti haritlaskond 1917-1940. Tallinn: Argo.

Kask, Arnold 1960. 40 aastat Emakeele Seltsi. - Emakeele Seltsi aastaraamat 6 (1960). Tallinn: Eesti Riiklik Kirjastus, lk 5-23.

Kask, Arnold 1970. Pool sajandit Emakeele Seltsi. - Emakeele Seltsi aastaraamat 16 (1970). Tallinn: Eesti Raamat, 1k 7-30.

Leivategija, Jürgen 2011. Perekonnanimede eestistamine kui kultuuriajalooline protsess: Seltskondlike organisatsioonide roll kampaanias ja selle tausta kujundamisel aastatel 1921-1940. Bakalaureusetöö. Tallinna Ülikool, Ajaloo Instituut.

Lepp, A. 1936. Perekonnanimede statistika. - Eesti Statistika, nr 5, lk 264-267.

MN 1935 = Muudetud nimede register. I: 1919 kuni 1. juuli 1935. Toim August Juhan Rava. Tallinn: Aura.

Must, Aadu 1999. Perekonnanimede eestistamine. - Maakodu, nr 1, lk 6-7.

Must, Aadu 2000. Eestlaste perekonnaloo allikad. 2., parand ja täiend tr. Tartu: Ajalookirjanduse Sihtasutus Kleio.

Must, Aadu 2006. Names as sources. The implementation of Estonian surnames in the historical research. - Proceedings of the $21^{\text {st }}$ International Congress of Onomastic Sciences. Uppsala 19-24 August 2002. Kd 2. Toim Eva Brylla, Mats Wahlberg koostöös Lars-Erik Edlundiga. Uppsala: Språk- och folkminnesinstitutet, lk 214-221.

Must, Aadu 2010. Name formation, name change and name loss. An Estonian case (18261940). - Proceedings of the $21^{\text {st }}$ International Congress of Onomastic Sciences. Uppsala 19-24 August 2002. Kd 5. Toim Eva Brylla, Maria Ohlsson, Mats Wahlberg koostöös Wolfgang Haubrichsi ja Tom Schmidtiga. Uppsala: Språk- och folkminnesinstitutet, lk 393-400.

Must, Aadu 2015. Perekonnaloo uurija käsiraamat. Tallinn: Hea Lugu.

Must, Hildegard 1957. Eestlaste perekonnanimedest. - Tulimuld, nr 6, lk 279-285.

Mõistlik, Piret 2005. Isikunime õiguslik korraldus. Nimeseaduse kommentaarid. Tallinn: Juura.

Nimede eestistamine $1987=$ Nimede eestistamine poole sajandi eest. - Eesti Päevaleht $=$ Estniska Dagbladet 3. VI, nr 43, lk 4.

Närhi, Eeva Maria 1987. The changing of surnames in Finland during the twentieth century, particularly in 1906 and 1935. - Studia Anthroponymica Scandinavica, kd 5, lk 109-121.

PENA 1921-1923 = Petserimaal ja Narvatagusel 1921-1923 pandud perekonnanimed. Andmebaas peamiselt kartoteegi (RA, EAA.5433.1.11 kuni 48) alusel. Koostanud Fred Puss, Eha Otsa, Mall Pendin. Fred Pussi valduses.

Puss, Fred 2020. Muuga või Kersna? Eesti rööpsete perekonnanimede teke ja kadu. - Eesti ja soome-ugri keeleteaduse ajakiri. Journal of Estonian and Finno-Ugric Linguistics, kd 11, nr 1, lk 43-85. https://doi.org/10.12697/jeful.2020.11.1.03

Põhjaklane 1935. Nimede muutmisel maal suur poolehoid. - Oma Maa 21. I, nr 9.

Pärn, Aveli 2013. Perekonnanimede eestistamine Tormas aastatel 1935-1940. Bakalaureusetöö. Tartu Ülikool, soome-ugri osakond. https://dspace.ut.ee/handle/10062/31614

Raag, Arno 1971. Kõuepilvede saatel. Mälestusi. Lund: Eesti Kirjanike Kooperatiiv. 
Raidmaa, Ilona 1999. Perekonnanimede muutmise ja eestistamise liikumine Eestis 1918-1940. Muudetud ja eestistatud nimed Anija, Peningi, Raasiku ja Rae vallas. Seminaritöö. Tartu Ülikool, eesti keele õppetool. https://murdearhiiv.ut.ee/naita.php?t=kasikiri\&id=5197

Rajandi, Edgar 1978. Mõtteid Eesti isikunimede uurimisest. - Sõna ja nimi. Emakeele Seltsi aastaraamat 23 (1977). Tallinn: Eesti Raamat, lk 93-102.

Rajandi, Edgar; Tarand, Helmut 1976. Eesti nimi läbi sajandite. - Keel, mida me uurime. Koost Mart Mäger. Tallinn: Valgus, lk 131-136.

Rajasalu, Inda 1993. Riiklik Propaganda Talitus ja eesti nimi. - Tundmatu Eesti Vabariik. Koost Jüri Ant, Eero Medijainen, Ago Pajur. Tallinn: Jaan Tõnissoni Instituut, lk 96-108.

Raun, Toivo U. 2012. The movement to Estonianize surnames in interwar Estonia. - Acta Historica Tallinnensia, kd 18, nr 1, lk 97-107. https://doi.org/10.3176/hist.2012.1.04

Reiman, H. 1936. Asustamistihedus ja rahvaarvu muutumine Eestis. - Eesti Statistika, nr 4, lk 169-176.

Roos 1980 = Sõnade ja nimede seltsis: Eduard Roos. [Intervjuu]. - Eesti sõnavara. Emakeele Seltsi aastaraamat 24 (1978). Tallinn: Eesti Raamat, lk 67-79.

RT = Riigi Teataja. 1918-1940.

RTL = Riigi Teataja Lisa. 1921-1940.

Salurand $1935=33000$ uuenimelist. [Vestlus hr Salurannaga Nimede Eestistamise Keskbüroost]. - Postimees 14. X, nr 280.

Staltmane 1977 = V. E. Staltmane, Iz istorii latyšskih familij. - Istoričeskaja onomastika. Otdel'nyi ottisk. Akademija nauk SSSR, Institut jazykoznanija. Moskva: Nauka, lk 159-180 [В. Э. Сталтмане, Из истории латышских фамилий. - Историческая ономастика. Отдельный оттиск. Академия наук СССР, Институт языкознания. Москва: Наука.]

Zetterberg, Seppo 2010. Eesti ajalugu. 4., parand ja täiend tr. Tallinn: Tänapäev.

Tamm, Marek 2020. Eesti ajalooteadus 21. sajandil: Sissejuhatuseks. - Acta Historica Tallinnensia, kd 26, nr 1, lk 3-45. https://doi.org/10.3176/hist.2020.1.01

Teder, Teofil 1939. Perekonnaseisuametniku käsiraamat. Tallinn: Siseministeeriumi Administratiiv-ala Kirjastus.

UN $1935=4000$ uut nime. Kuidas leida uut perekonnanime. Viljandi: Oma Maa.

US 1921 = 15.000 uut sugunime. Lisa albumile „Eestlasele Eesti nimi”. (Akadeemilise Emakeele Seltsi toimetused IV.) Tartu: Akadeemiline Emakeele Selts.

Uut hoogu 1940 = Uut hoogu nimede eestistamisel. - Sakala 1. IV, nr 37, 1k 3.

Vaan, Laura 2005. Propagandatalitus Eesti Vabariigis autoritaarsel ajajärgul. Magistritöö. Tartu Ülikool, Eesti ajaloo õppetool. http://dspace.ut.ee/handle/10062/1208

Walkowiak, Justyna B. 2016. Personal Name Policy: From Theory to Practice. (Dysertacje Wydziału Neofilologii UAM w Poznaniu 4.) Poznań: Wydział Neofilologii UAM w Poznaniu. https://doi.org/10.14746/9788394601720

VT $1934=$ Valitsusasutiste tegevus 1918-1934. Tallinn: Riigikantselei.

VT $1939=$ Valitsusasutiste tegevus 1938/39. a. Tallinn: Riigikantselei.

Fred Puss (snd 1976), Eesti Keele Instituudi leksikograaf-nooremteadur; Tartu Ülikooli ajaloo ja arheoloogia instituudi doktorant (Jakobi 2-222, 51014 Tartu), fred.puss@eesti.ee 


\section{Changing Kakason to Kaljula: Analysing database of Estonianizing surnames}

Keywords: anthroponymics, surnames, Estonian history, name changes, national campaigns

Surname changes have taken place throughout their existence, but not so often as a result of a nationwide campaign. In Estonia campaign of Estonianizing foreign (mostly German) sounding names took place in 1920-1944 with 99\% of the name changes taking place in 1935-1940. It stands out for its intenseness which resulted a surname change of every sixth person. Also, public access to the complete database of name changes already since the 1990s (www.ra.ee/apps/onomastika/) is unique when compared to other countries. Author of this article has amended the public version of the database for the last two decades and explains the arisen problems with it.

This article uses new data analysis methods to correct the total number of surname changers during the campaign (see Table 1). The resulting number of approximately 195,000 is smaller than has been estimated so far $(210,000)$. Estonian population at that time was 1.13 million, thus the amount of name changers was $17 \%$.

New names were often taken from a 1935 book of suggested surnames titled Eesti nimi ("Estonian name"). The book contains 15,595 suggested names and 30\% of them were actually taken as a new name. Also $30 \%$ of all taken names (37\% when counting all individual name changes) come from the book, in some municipalities even up to $83 \%$. The public preferred shorter names from the book and the use of the book slightly increased year by year (see Figures 2 and 3). Average length of all taken names was seven letters (69\% took a name with 6 to 8 letters), the most popular first letters being $k(13 \%), r(11 \%)$ and $l(10 \%)$.

The first letter of the old and new name matches in $57 \%$ cases, most popular preserved first letters being $r$ and $l$ (both $77 \%$, see Figure 1). Tendency of preserving the first letter also increased in time. $10 \%$ of the names were taken only once, with the highest (up to 29\%) number in municipalities of Petseri county. Taking an unique name also slightly increased in time. Almost the Pareto rule applies to surname changers: $73 \%$ of name changers used $22 \%$ of the overall choice of taken names.

Many more analyses can be made with the huge database, for example analysis of the vocabulary used in taken names, aesthetically motivated name changes, reused names (for example taking a wife's maiden name as a new surname), geographicalchronological dynamics of name changes etc.

Fred Puss (b. 1976), Institute of the Estonian Language, Lexicographer-Junior Researcher; University of Tartu, Institute of History and Archaeology, PhD Student (Jakobi 2-222, 51014 Tartu), fred.puss@eesti.ee 